\title{
W SPRAWIE POJĘCIA EKOLOGICZNEGO RYNKU KAPITAŁOWEGO
}

\section{THE NOTION OF GREEN CAPITAL MARKET}

\author{
http://dx.doi.org/10.12775/PPOS.2016.008
}

\section{STRESZCZENIE}

W ostatnim czasie można zaobserwować proces legislacyjnego zbliżania się do siebie dziedziny prawa ochrony środowiska oraz prawa rynku kapitałowego. Staje się on coraz bardziej intensywny, a punkty styczne obejmują coraz więcej płaszczyzn. Zainspirowana tymi okolicznościami publikacja podejmuję próbę pojęciowego osadzenia nowej kategorii dogmatycznej - ekologicznego rynku kapitałowego - w realiach dogmatyki prawa ochrony środowiska oraz prawa rynku kapitałowego.

* Dr hab., Katedra Prawa Cywilnego i Bankowego, Wydział Prawa i Administracji Uniwersytetu Mikołaja Kopernika w Toruniu. 


\section{Słowa kluczowe}

Ekologiczny rynek kapitałowy; rynek kapitałowy; prawo ochrony środowiska; instrumenty finansowe; instrumenty finansowe ekologicznego rynku kapitałowego.

\section{ABSTRACT}

A legislative process of two areas of law: the environmental law and the capital market law approaching each other may be observed recently. This process is becoming more and more intense and the points of contact between those areas of law cover more and more fields. This publication, inspired by the above-mentioned circumstances, attempts to provide a conceptual framework for new dogmatic category - so called green capital market - in the dogmatic reality of environmental law and capital market law.

\section{Keywords}

Green capital market; capital market; environmental law; financial instruments; financial instruments of the green capital market.

\section{WSTĘP}

Dnia 9 września 2015 roku weszła w życie ustawa z dnia 12 czerwca 2015 roku o systemie handlu uprawnieniami do emisji gazów cieplarnianych ${ }^{1}$. Nowy akt prawny uchyla wcześniej obowiązujący pod identyczną nazwą ${ }^{2}$. Modyfikuje też w znacznym stopniu reżim pierwotnego oraz wtórnego rynku uprawnień do emisji gazów cieplarnianych, chociaż bez uszczerbku dla podstawowych założeń systemowych. Instytucje prawne znane wcześniej utrzymały się na swoich pozycjach. Dotyczy to m.in. rejestru uprawnień do emisji gazów cieplarnianych do at-

1 Dz. U. z 2015 r., poz. 1223.

2 Tj. ustawę z dnia 28 kwietnia 2011 roku o systemie handlu uprawnieniami do emisji gazów cieplarnianych (Dz. U. Nr 122, poz. 695 ze zm.). 
mosfery, konstrukcji prawnej uprawnień do emisji jako zbywalnych praw podmiotowych wpisanych na rachunek, panującego modelu przydziału uprawnień instalacjom emisyjnym, głównych założeń przeprowadzania aukcji uprawnień do emisji, czy też zasady licencjonowania instalacji emisyjnych.

Odnotowanie legislacyjnych zmian w obrębie systemu handlu uprawnieniami do emisji gazów cieplarnianych - ważkich z praktycznego punktu widzenia - nasuwa jednak również jednoznaczną myśl o zbliżaniu się do siebie prawa ochrony środowiska oraz prawa rynku kapitałowego. Pomimo innych różnych względów stało się to właśnie faktem umocowanym normatywnie. Nowa ustawa o systemie handlu uprawnieniami do emisji gazów cieplarnianych znowelizowała ustawę o nadzorze nad rynkiem kapitałowym ${ }^{3}$. W wyniku tej nowelizacji jednym z elementów definicji ustawowej rynku kapitałowego stało się pojęcie wywodzące się z prawa ochrony środowiska. Trudno o bardziej przemawiające świadectwo przenikania się obu dyscyplin dogmatyki prawa.

Od niedawna definicja ustawowa rynku kapitałowego przewidziana w art. 2 pkt 6 u.n.r.k. obejmuje nie tylko rynek papierów wartościowych i innych instrumentów finansowych, rynek usług świadczonych przez fundusze inwestycyjne i inne instytucje wspólnego inwestowania, rynek towarów giełdowych, ale również - co stanowi novum - rynek dwudniowych kontraktów na rynku kasowym, o których mowa w art. 3 ust. 1 pkt 3 rozporządzenia 1031/20104 w zakresie, w jakim do obrotu tymi uprawnieniami do emisji stosuje się przepisy tego rozporządzenia.

Poszerzenie zakresu definicji rynku kapitałowego nie będzie przedmiotem głównego zainteresowania. Należy jednak

3 Ustawa z dnia 29 lipca 2005 roku o nadzorze nad rynkiem kapitałowym (tekst jedn. Dz. U. z 2014 r., poz. 1537 ze zm.); dalej u.n.r.k.

4 Rozporządzenie Komisji (UE) nr 1031/2010 z dnia 12 listopada 2010 roku w sprawie harmonogramu, kwestii administracyjnych oraz pozostałych aspektów sprzedaży na aukcji uprawnień do emisji gazów cieplarnianych na mocy dyrektywy 2003/87/WE Parlamentu Europejskiego i Rady ustanawiającej system handlu przydziałami emisji gazów cieplarnianych we Wspólnocie (Dz. Urz. UE L 302 z 18.11.2010, s. 1 ze zm.). 
odnotować, że de lege lata - w świetle art. 3 ust. 1 pkt 3 rozporządzenia 1031/2010 - dwudniowe kontrakty na rynku kasowym oznaczają uprawnienia (do emisji gazów cieplarnianych) sprzedawane na aukcji $\mathrm{z}$ dostawą $\mathrm{w}$ uzgodnionym terminie przypadającym nie później niż drugiego dnia handlowego od dnia aukcji, na mocy art. 38 ust. 2 lit. a) rozporządzenia (WE) nr $1287 / 2006^{5}$. Ten ostatni przepis przewiduje zaś, ujmując w pewnym uproszczeniu, że kontrakt na rynku kasowym oznacza kontrakt na sprzedaż towaru, aktywów lub prawa, zgodnie $\mathrm{z}$ warunkami którego dostawa ma nastąpić w terminie dwóch dni handlowych.

Nie wchodząc w skomplikowane szczegóły związane z określeniem zakresów pojęć zastosowanych przez ustawodawcę (polskiego i unijnego), należy skwitować, że chodzi tutaj o jedną z postaci przedmiotu świadczenia w umowie sprzedaży, który należy do kategorii praw podmiotowych wpisanych na rachunek (czyli jest walorem zdematerializowanym), przewidujących w swojej treści możliwość wypuszczenia do atmosfery określonej ilości zanieczyszczeń. Przedmiot sprzedaży może podlegać tzw. dostawie fizycznej („wydaniu” przez dokonanie wpisu na rachunek osoby uprawnionej). W wyniku tego rynek kasowych instrumentów kształtowania polityki ochrony środowiska stał się częścią polskiego rynku kapitałowego. Takie ujęcie jest w pewnym sensie wyrazem niekonsekwencji ustawodawcy (zwłaszcza unijnego), ponieważ tzw. dwudniowe kontrakty na rynku kasowym nie zostały zakwalifikowane do nadrzędnej kategorii instrumentów finansowych, ale pomimo tego są objęte reżimem prawnym właściwym dla sektora obrotu instrumentami finansowymi. I chociaż de lege lata nadzór sprawowany przez KNF obejmuje także walory, które nie mieszczą się w granicach pojęcia instrumentu finansowego, to nowelizacja ustawy o nad-

5 Rozporządzenie Komisji (WE) nr 1287/2006 z dnia 10 sierpnia 2006 roku wprowadzające środki wykonawcze do dyrektywy 2004/39/WE Parlamentu Europejskiego i Rady w odniesieniu do zobowiązań przedsiębiorstw inwestycyjnych $\mathrm{w}$ zakresie prowadzenia rejestrów, sprawozdań z transakcji, przejrzystości rynkowej, dopuszczania instrumentów finansowych do obrotu oraz pojęć zdefiniowanych na potrzeby tejże dyrektywy (Dz. Urz. UE L 241 z 2.9.2006, s. 1). 
zorze nad rynkiem kapitałowym przez ustawę o systemie handlu uprawnieniami do emisji gazów cieplarnianych świadczy o efektywnym zharmonizowaniu prawa polskiego z prawem unijnym, ponieważ jest efektem procesu implementacji tego ostatniego. Świadczy również jednak o skomplikowanym kształcie systemu handlu uprawnieniami do emisji gazów cieplarnianych i o przenikaniu się różnych rationes decydujących o treści prawa obowiązującego w dziedzinie rynku kapitałowego w skali europejskiej.

\section{FORMALNOPRAWNE POJĘCIE EKOLOGICZNEGO RYNKU KAPITAEOWEGO}

Pojęcie ekologicznego rynku kapitałowego należy do pojęć pozaprawnych. Nie występuje w aktach prawnych. Jest raczej pojęciem obiegowym języka potocznego (gospodarczego i publicystycznego). Analiza przepisów obecnie obowiązującego prawa, w tym przede wszystkim przepisów składających się na szeroko pojmowane prawo rynku kapitałowego, stwarza jednak podstawę sformułowania wniosku o głębokim zakotwiczeniu pojęcia ekologicznego rynku kapitałowego w systemie prawa de lege lata. Osiągnięcie takiej konkluzji jest możliwe po przeanalizowaniu podstawowych pojęć obowiązującego w Polsce prawa rynku kapitałowego pod kątem związanych z ochroną środowiska elementów norm wybranych instytucji prawnych. Obecnie obowiązującemu prawu rynku kapitałowego znane są instytucje prawne o orientacji ekologicznej.

Klasycy prawa pojmują definiowanie jako wskazanie rodzaju i różnicy gatunkowej (definitio fit per genus proximum et differentiam specificam). Opierając się na tym jasnym założeniu, ustalenie treści pojęcia „ekologiczny rynek kapitałowy” wymaga w pierwszej kolejności ustalenia treści pojęcia „rynek kapitałowy”, a następnie ustalenie różnicy pomiędzy rynkiem kapitałowym „konwencjonalnym” („zasadniczym”, „podstawowym”) oraz „ekologicznym”.

Pierwsze zadanie nie nastręcza szczególnych trudności. Pojęcie rynku kapitałowego jest bowiem zdefiniowane 
w przepisach prawa rynku kapitałowego i zostało już wyżej schematycznie przybliżone. Jeżeli natomiast chodzi o „ekologiczne" odniesienia w dziedzinie rynku kapitałowego, to mają one zróżnicowany charakter. Można je ujmować z perspektywy przedmiotu świadczenia $\mathrm{w}$ umowie sprzedaży (rynek ekologicznych instrumentów kapitałowych) oraz z perspektywy osób wchodzących w stosunki ekologicznego rynku finansowego (rynek uczestników ekologicznego rynku kapitałowego). W zaproponowanej kolejności obie perspektywy zostaną omówione poniżej.

\section{WALORY (INSTRUMENTY) EKOLOGICZNEGO RYNKU KAPITAEOWEGO}

\subsection{SEGMENTACJA RYNKU WALORÓW EKOLOGICZNEGO RYNKU KAPITAEOWEGO}

Walor rynku kapitałowego jest przedmiotem świadczenia wynikającego z umowy sprzedaży zawartej pomiędzy uczestnikami rynku kapitałowego. Tę dość klarowną definicję można uszczegółowić pod kilkoma względami, w celu ustalenia treści pojęcia walorów (instrumentów) ekologicznego rynku kapitałowego.

Dla obowiązującego ustawodawstwa w dziedzinie rynku kapitałowego podstawowe znaczenie ma pojęcie rynku regulowanego, przewidziane w przepisie art. 14 ust. 1 ustawy z dnia 29 lipca 2005 roku o obrocie instrumentami finansowymi ${ }^{6}$. Rynek regulowany to działający w sposób stały system obrotu instrumentami finansowymi dopuszczonymi do tego obrotu, zapewniający inwestorom powszechny i równy dostęp do informacji rynkowej w tym samym czasie przy kojarzeniu ofert nabycia i zbycia instrumentów finansowych oraz jednakowe warunki nabywania i zbywania tych instrumentów, zorganizo- 
wany i podlegający nadzorowi właściwego organu na zasadach określonych w przepisach ustawy, jak również uznany przez państwo członkowskie za spełniający te warunki i wskazany Komisji Europejskiej jako rynek regulowany.

Przytoczenie tej definicji ustawowej nie tylko wypełnia treścią jedno z pojęć tzw. słowniczka ustawowego, ale jest również podstawą określenia zakresu rynku kapitałowego niepoddanego szczegółowej reglamentacji, a zatem nie spełniającego kryteriów rynku regulowanego. Negatywem rynku regulowanego jest rynek nieregulowany, czyli rynek wolny. W nomenklaturze praktyków rynku kapitałowego ukrywa się on pod nazwą OTC (over-the-counter), przy czym „lada” (counter; kontuar) jest rozumiana jako wywodzący się z ustawowej definicji rynku regulowanego „działający w sposób stały system obrotu instrumentami finansowymi”, inaczej mówiąc - pakiet giełdowy. Czynności dokonywane poza „systemem” (poza kontuarem, poza giełdą oraz poza innymi platformami rynku regulowanego) nie mieszczą się w granicach pojęcia rynku regulowanego. Podstawą ich dokonywania i oceny prawnej są przepisy powszechnego prawa cywilnego (przede wszystkim kodeksu cywilnego oraz kodeksu spółek handlowych).

Opierając się na tym wyjściowym założeniu można przyjąć, że walor giełdowy jest przedmiotem świadczenia wynikającego z umowy sprzedaży zawartej na giełdzie i analogicznie - przez zanegowanie - walor rynku wolnego (OTC) jest przedmiotem świadczenia wynikającego z umowy sprzedaży zawartej na podstawie przepisów powszechnego prawa cywilnego. Ta konkluzja stanowi zaś punkt wyjścia do przyjęcia (i wykazania prawidłowości) wniosku, że walory ekologicznego rynku kapitałowego mają charakter dualistyczny, patrząc na sprawę z perspektywy kryterium prawnych podstaw obrotu cywilnoprawnego pomiędzy zbywcą a nabywcą. Mianowicie, walory ekologicznego rynku kapitałowego są przedmiotem obrotu zarówno na rynku regulowanym (zwłaszcza giełdowym), jak i poza rynkiem regulowanym, czyli w ramach rynku wolnego (OTC).

Należy zatem dokonać przeglądu obu kategorii, poprzedzając szczegółowe rozważania spostrzeżeniem, że tak rozu- 
miane walory ekologicznego rynku kapitałowego wpisują się $\mathrm{w}$ ustawową definicję towaru giełdowego. W świetle art. 2 pkt 2 ustawy z dnia 26 października 2000 roku o giełdach towarowych ${ }^{7}$ towarem są - m.in. - dopuszczone do obrotu na danej giełdzie towarowej lub do obrotu organizowanego zgodnie $\mathrm{z}$ odrębnymi przepisami limity wielkości produkcji lub emisji zanieczyszczeń, prawa majątkowe wynikające ze świadectw, o których mowa w ustawie z dnia 10 kwietnia 1997 r. - Prawo energetyczne ${ }^{8}$ oraz ze świadectw pochodzenia biogazu rolniczego, o których mowa w ustawie z dnia 20 lutego 2015 r. o odnawialnych źródłach energii ${ }^{9}$, niebędące instrumentami finansowymi prawa majątkowe, których cena zależy bezpośrednio lub pośrednio od ceny lub wartości oznaczonych co do gatunku rzeczy, określonych rodzajów energii, paliw gazowych, mierników i limitów wielkości produkcji, emisji zanieczyszczeń lub praw majątkowych, a także prawa majątkowe wynikające ze świadectwa efektywności energetycznej, o których mowa w art. 25 ust. 1 ustawy z dnia 15 kwietnia 2011 r. o efektywności energetycznej ${ }^{10}$.

\subsection{EKOLOGICZNE WALORY GIEŁDOWE}

W obrocie giełdowym - w Polsce na Towarowej Giełdzie Energii S.A. (dalej TGE S.A.) - notowane są zróżnicowane walory pod względem ucieleśniających praw podmiotowych odnoszące się z poszanowaniem do postulatu ochrony środowiska naturalnego. Przede wszystkim w rachubę wchodzą prawa majątkowe do świadectw pochodzenia energii z odnawialnych źródeł, tzw. kolorowych certyfikatów, występujących w kilku barwach (zielonym, czerwonym, żółtym, fioletowym, pomarańczowym, błękitnym, białym i brązowym).

7 Tekst jedn. Dz. U. z 2014 r., poz. 197 ze zm.; dalej u.g.t.

8 Tekst jedn. Dz. U. z 2012 r. poz. 1059 ze zm.

9 Dz. U. z 2015 r., poz. 478 ze zm.

10 Dz. U. Nr 94, poz. 551, ze zm. 
Ogólnie rzecz biorąc, tzw. kolorowy certyfikat jest środkiem symbolizującym prawo podmiotowe osoby, która wyprodukowała energię z odnawialnych źródeł, jako świadectwo potwierdzające fakt pochodzenia energii elektrycznej z odnawialnych źródeł. Treść prawa podmiotowego wynikającego ze świadectwa pochodzenia energii z odnawialnych źródeł sprowadza się do odcinka legitymacyjnego. Kolorowy certyfikat ma pod tym względem status zaświadczenia (potwierdzenia faktu, dowodu na określoną okoliczność).

Świadectwa pochodzenia energii z odnawialnych źródeł są wydawane (w formie dokumentu) na wniosek producenta energii przez Prezesa Urzędu Regulacji Energetyki, po uzyskaniu przez wnioskodawcę potwierdzenia ilości wyprodukowanej energii, czego dokonuje operator systemu dystrybucyjnego na podstawie wskazań licznika. Świadectwa pozostające w sferze obrotu dokumentowego nie mogą zostać wykorzystane w obrocie giełdowym. Niezbędne jest do tego „zdematerializowanie” praw podmiotowych wynikających ze świadectwa. Procedurę dematerializacji inicjuje Prezes Urzędu Regulacji Energetyki, który po wystawieniu świadectwa w postaci dokumentowej przesyła w formie elektronicznej informację do Rejestru Świadectw Pochodzenia prowadzonego przez TGE S.A. Po założeniu rachunku w Rejestrze Świadectw Pochodzenia osoba uprawniona na podstawie świadectwa staje się wierzycielem w stosunku rachunku oraz uzyskuje status osoby, której służą „prawa majątkowe do świadectw pochodzenia". Wpis na rachunku (na koncie) w Rejestrze jest nośnikiem praw podmiotowych występujących pod tą nazwą. Pod względem swojej treści poszczególne typy praw majątkowych (tj. PMOZE, PMOZE_A, PMGM, PMMET, PMEC, PMBG oraz PMEF) odpowiadają - w pewnym uproszczeniu poszczególnym kolorom certyfikatów. Prawa majątkowe do świadectw pochodzenia są zbywalne. Mogą więc zostać przeniesione przez osobę pierwotnie legitymowaną (producenta energii) w drodze czynności prawnej na inną osobę, a zatem mają cenę, która kształtuje się w wyniku skonfrontowania ze sobą popytu i podaży. 
Oprócz tego przedmiotem obrotu giełdowego są uprawnienia do emisji dwutlenku węgla do atmosfery ${ }^{11}$. Unijny system obrotu prawami podmiotowymi tej treści (EU ETS; The European Union Emissions Trading System), opierający się na ustaleniach Protokołu z Kioto, przewiduje systematyczną redukcję emisji zanieczyszczeń do atmosfery. Przyjęto jednak, że minimalizacja skali emisji nie może nastąpić gwałtownie i od razu. Dlatego producentom zanieczyszczeń wyziewanych do atmosfery (instalacjom emisyjnym) nieodpłatnie przydzielane są limity (kwoty) dopuszczalnych emisji, coraz bardziej malejące (co ma wymusić minimalizację skali zanieczyszczeń). Uprawnienie do emisji dwutlenku węgla do atmosfery w pewnym sensie zastępuje szkodliwe dla środowiska oddziaływania, ponieważ pula przydzielonych uprawnień z założenia ma być równa ilości wyemitowanych zanieczyszczeń. Jeżeli przedsiębiorca zarządzający instalacją emisyjną w zakładanym okresie rozliczeniowym (aktualnie lata 2013-2020) wyemituje do atmosfery więcej zanieczyszczeń, niż suma posiadanych uprawnień (w wyniku nieodpłatnego przydziału), to jest zobowiązany do zapłacenia wysokiej kary administracyjnej ${ }^{12}$. Obowiązku zapłaty może uniknąć w drodze przedstawienia do umorzenia uprawnień nabytych od innej osoby. Jeżeli zaś przedsiębiorca zarządzający instalacją emisyjną w zakładanym okresie rozliczeniowym wyemituje mniej zanieczyszczeń, to może uzyskane nieodpłatnie uprawnienia sprzedaży. Podaż i popyt na uprawnienia do emisji dwutlenku węgla do atmosfery są więc pochodną rzeczywistej ilości wypuszczonego do atmosfery fizycznego dwutlenku węgla.

11 Jak dotąd obroty na TGE S.A. w zakresie uprawnień do emisji dwutlenku węgla do atmosfery nie uzyskały znaczących wartości. Dominujące znaczenie rynkowe mają giełdy zagraniczne, m.in. European Energy Exchange (EEX) $\mathrm{z}$ siedzibą w Lipsku oraz Intercontinental Exchange Futures Europe (ICE Futures Europe) z siedzibą w Londynie.

12100 euro za każdą tonę wypuszczonego do atmosfery dwutlenku węgla nieskompensowanego w drodze przedstawienia do umorzenia uprawnień do emisji (na podstawie art. 104 ustawy z dnia 12 czerwca 2015 roku o systemie handlu uprawnieniami do emisji gazów cieplarnianych; Dz. U. poz. 1223 ze zm.). 
Na tym klarownym schemacie konstrukcyjnym opiera się system obrotu uprawnieniami do emisji dwutlenku węgla do atmosfery. Uprawnieniom został nadany status zbywalnych praw podmiotowych. Niedawno - wraz z wejściem w życie dyrektywy MiFID 2 z 2014 roku - uzyskały one status instrumentów finansowych. Także to świadczy o przedostawaniu się pojęć prawa ochrony środowiska na obszar tradycyjnie zarezerwowany dla prawa rynku kapitałowego.

Powyższe kategorie (prawa majątkowe do świadectw pochodzenia oraz uprawnienia do emisji dwutlenku węgla do atmosfery) można traktować jako walory ekologicznego rynku kapitałowego w ścisłym rozumieniu. W wymiarze znacznie szerszym do kategorii „ekologicznych” można zakwalifikować walory udziałowe (akcje) tych emitentów giełdowych (spółek publicznych), którzy uwzględniają w ramach swojej działalności normatywne założenia prawa ochrony środowiska, a niezależnie od tego deklarują też przestrzeganie norm tzw. prawa miękkiego (w ramach szeroko rozumianego corporate governance). Ten obszar (sensu largo) oddziaływania ideologii ekologicznej na rynku kapitałowym mieści się w granicach pojęciowych społecznej odpowiedzialności biznesu (ang. Corporate Social Responsibility, CSR). Kryteria ekologiczne przedostały się zresztą nawet na obszar szczegółowych instytucji prawa i praktyki giełdowej. Wyrazem tej tendencji jest m.in. Respect Index (ogłaszany przez GPW w Warszawie S.A.), do którego kwalifikowane są akcje wąskiej grupy emitentów przestrzegających m.in. podstawowych założeń prawa ochrony środowiska, w ramach deklarowanego przestrzegania podstawowych założeń społecznie odpowiedzialnego biznesu oraz corporate governance.

\subsection{WALORY EKOLOGICZNEGO RYNKU KAPITALOWEGO W OBROCIE WOLNYM (OTC)}

Skierowanie walorów ekologicznego rynku kapitałowego do notowań giełdowych nie jest imperatywem. Ustawodawca jak dotąd nie przewidział obligu notowania na giełdzie walorów ekologicznego rynku kapitałowego. Postulat tej treści nie 
jest też stawiany. Giełda jest źródłem udogodnień, a nie rozwiązaniem przymusowym. Dlatego zarówno tzw. kolorowe certyfikaty, jak również prawa majątkowe do świadectw pochodzenia energii z odnawialnych źródeł oraz uprawnienia do emisji dwutlenku węgla do atmosfery mogą być przedmiotem świadczenia w umowie sprzedaży zawieranej na podstawie przepisów powszechnego prawa cywilnego. Cyrkulacja walorów ekologicznego rynku kapitałowego w obrocie wolnym, w ramach OTC, jest możliwa i w praktyce często spotykana.

Wydawałoby się więc, że zbywcą i nabywcą takiego prawa podmiotowego może być każda osoba prawa prywatnego. Na pierwszy rzut oka zbywcą może być osoba, której służą prawa podmiotowe do świadectw pochodzenia albo uprawnienia do emisji dwutlenku węgla do atmosfery, natomiast nabywcą każda inna osoba. Na drodze do przyjęcia takiej konkluzji stoją dwojakiego rodzaju przeszkody - pragmatyczne i jurydyczne. Z tych dwóch względów cyrkulacja walorów ekologicznego rynku kapitałowego na rynku wolnym (OTC) odbywa się w ograniczonych kręgach podmiotowych i nie jest dostępna dla każdej osoby prawa cywilnego.

Po pierwsze, z pragmatycznego punktu widzenia pierwotnym zbywcą wspomnianych walorów może być tylko osoba, której służy status pierwotnie uprawnionego, czyli producent energii z odnawialnych źródeł („posiadacz” praw majątkowych do świadectw pochodzenia) albo instalacja emisyjna („posiadacz" nieodpłatnie uzyskanych uprawnień do emisji). Gospodarczy interes $\mathrm{w}$ nabyciu tej treści praw podmiotowych mają osoby, które mogą zrobić z nich użytek (wykorzystać w swojej działalności). W przypadku praw majątkowych do świadectw pochodzenia energii z odnawialnych źródeł oraz w przypadku uprawnień do emisji dwutlenku węgla do atmosfery będą to przede wszystkim producenci energii ze źródeł konwencjonalnych, czyli instalacje emisyjne. Inne osoby prawa cywilnego nie mają faktycznego interesu w posiadaniu walorów ekologicznego rynku kapitałowego, ponieważ nie mają gospodarczej motywacji do wykorzystania ich właściwości jurydycznych - czyli 2/2016 przedstawienia do umorzenia. 
Przechodząc - po drugie - do przybliżenia prawnych ograniczeń ekspansji rynku walorów ekologicznych wśród szerokiej (masowej) publiczności należy zauważyć, że pod względem konstrukcji prawnej opierają się one na schemacie obligacyjnego stosunku rachunku. Rachunek (zwany też kontem albo rejestrem) jest prowadzony przez osobę, która występuje w roli dłużnika zobowiązanego do prowadzenia rachunku. Głównym obowiązkiem osoby prowadzącej rachunek jest dokonywanie wpisów na rachunek. W stosunku rachunku wierzycielem jest osoba uprawniona z prawa majątkowego do świadectwa pochodzenia energii z odnawialnych źródeł oraz z uprawnienia do emisji dwutlenku węgla do atmosfery. $\mathrm{Z}$ tego względu pierwotnym zbywcą wspomnianych walorów może być tylko osoba, której służy status pierwotnie uprawnionego - czyli osoba, która „posiada” w systemie rachunek prowadzony przez osobę do tego zadania wyznaczoną. Dlatego każda osoba prawa cywilnego, która pożądałaby waloru ekologicznego rynku kapitałowego w swoim majątku powinna „posiadać” rachunek. Bez tego nie da się osiągnąć skutku rozporządzającego w majątku zbywcy oraz nabywcy, ponieważ walory ekologicznego rynku kapitałowego mają charakter zdematerializowany, w sensie prawnym stanowią prawo podmiotowe wynikające $\mathrm{z}$ wpisu na rachunek, a zatem przechodzą ze zbywcy na nabywcę przez wpis na rachunek dokonywany przez osobę prowadzącą rachunek.

Zgodnie z podstawowymi założeniami prawa prywatnego przejście prawa podmiotowego ze zbywcy na nabywcę wymaga zawarcia umowy zobowiązującej do rozporządzenia oraz - bez wyjątku - spełnienia świadczenia przez zbywcę na rzecz nabywcy. Zbywca waloru ekologicznego rynku kapitałowego nie może jednak spełnić świadczenia na rzecz nabywcy osobiście, ponieważ nie prowadzi jego rachunku. Wykonanie zobowiązania przez zbywcę na rzecz nabywcy wymaga aktywności osoby trzeciej, prowadzącej rachunek w systemie, polegającej na dokonaniu rozrachunku („rozksięgowania”) transakcji, co sprowadza się do obciążenia rachunku zbywcy oraz uznania rachunku nabywcy. W ten sposób prawo podmiotowe wpisane na rachunek przechodzi ze zbywcy na nabywcę. 


\section{PODMIOTY (UCZESTNICY) EKOLOGICZNEGO RYNKU KAPITAŁOWEGO}

W ujęciu podmiotowym ekologiczny rynek kapitałowy jest reprezentowany przez te same kategorie osób, które występują również na arenie „konwencjonalnego” rynku kapitałowego. Wyraźnie zarysowuje się tutaj dwupodział na osoby handlujące oraz podmioty infrastruktury rynkowej.

Można powiedzieć, że źródłem podaży oraz popytu walorów ekologicznego rynku kapitałowego są osoby o konwencjonalnym statusie ,inwestora” - chociaż jest to pewne uproszczenie, ponieważ $\mathrm{w}$ praktyce pojedynczy walor ekologicznego rynku kapitałowego nie należy do kategorii dóbr wielokrotnie przechodzących z rak do rąk. Majątkowy interes zbywcy wiąże się z uzyskaniem środków pieniężnych z tytułu swego rodzaju bonifikaty za trud poświęcony na wyprodukowanie energii $\mathrm{z}$ odnawialnych źródeł (w przypadku praw majątkowych do świadectw pochodzenia) albo za trud poświęcony na zmniejszenie poziomu emisji zanieczyszczeń do atmosfery (w przypadku uprawnień do emisji). Natomiast majątkowy interes nabywcy wiąże się z obowiązkiem wykazania tytułu, z którego wynika fakt sprostania wymogowi wyprodukowania energii pochodzącej z odnawialnych źródeł albo zmniejszenia ilości zanieczyszczeń wypuszczonych do atmosfery. Walory ekologicznego rynku kapitałowego należą więc w pewnym sensie do kategorii walorów ,jednorazowego użytku” (jednokrotnej cyrkulacji), przechodząc w zasadzie jednorazowo z rąk osób dysponujących nadwyżką do rąk osób dysponujących deficytem czystej energii i zobowiązanych do pokrycia tego deficytu w sposób konwencjonalny. Ze względu na relatywnie niski stopień płynności oraz relatywnie mało gwałtowne wahania kursów w sektorze walorów ekologicznego rynku kapitałowego nie wykształciła się profesja zawodowego inwestora (tzw. „spekulanta”; kiedyś taką osobą był makler niezależny ${ }^{13}$ ). Dlatego można powiedzieć, że stronę podażową reprezentują producenci czystej energii,

13 Szerzej zob. K. Zacharzewski, Makler niezależny według przepisów ustawy o giełdach towarowych, PUG 2002, Nr 5, s. 9 i nast.; tenże, Wykonywanie 
w tym m.in. prosumenci (konsumenci wyprodukowanej przez siebie energii, którzy sprzedają niezużytą nadwyżkę), natomiast stronę popytową reprezentują przedsiębiorcy zarządzający instalacjami emisyjnymi. Prezentowana prawidłowość odnosi się zarówno do regulowanego (giełdowego) obrotu walorami ekologicznego rynku kapitałowego oraz do obrotu wolnego (OTC).

Jeżeli natomiast chodzi o wyróżniającą ekologiczny rynek kapitałowy kategorię podmiotów infrastruktury rynkowej, to należy wstępnie zauważyć, że w sektorze obrotu wolnego (OTC) znaczenie tej kategorii jest mniejsze, niż w przypadku obrotu regulowanego (giełdowego). W sektorze obrotu wolnego istotne znaczenie infrastrukturalne odgrywają wyłącznie osoby prowadzące rachunki walorów ekologicznego rynku kapitałowego (ponieważ rozporządzenie prawem podmiotowym wpisanym na rachunek wymaga dokonania wpisu na rachunek), a także pośrednicy rynkowi. Obie kategorie podmiotowe występują także w sektorze obrotu regulowanego (giełdowego) i dlatego zostaną omówione wspólnie.

Pod względem infrastrukturalnym podstawowym uczestnikiem regulowanego obrotu walorami ekologicznymi jest - oczywiście - spółka prowadząca giełdę. W polskich realiach w roli giełdy walorów ekologicznego rynku kapitałowego występuje Towarowa Giełda Energii S.A. Wszystkie akcje tej spółki należą do innego uczestnika rodzimego rynku kapitałowego - do Giełdy Papierów Wartościowych w Warszawie S.A. ${ }^{14}$. Do zadań tej osoby należy prowadzenie giełdy towarowej, rozumianej przez ustawodawcę jako zespół osób, urządzeń i środków technicznych zapewniających wszystkim uczestnikom obrotu jednakowe warunki zawierania transakcji giełdowych oraz jednakowy dostęp w tym samym czasie do informacji rynkowych, a w szczególności do informacji o kursach i cenach towarów giełdowych oraz o obrotach towarami giełdowymi (art. 2 pkt 1 u.g.t.).

działalności maklerskiej przez maklera niezależnego $w$ giełdowym obrocie towarowym, PUG 2002, Nr 11, s. 2 i nast.

14 Na GPW w Warszawie S.A. rynek towarowy - głównie rynek energii elektrycznej (poee; platforma obrotu energią elektryczną) - nie rozwinął się w oczekiwanym stopniu. 
Jak zatem okazuje się, definicyjne ujęcie giełdy towarowej $\mathrm{w}$ istotnym stopniu przypomina ujęcie rynku regulowanego przewidziane w art. 14 ust. 1 u.o.i.f. Zadania osoby prowadzącej giełdę towarową zbliżone są również do zadań osoby prowadzącej giełdę „finansową" (por. art. 4 u.g.t. oraz art. 18 ust. 1 u.o.i.f.). Ustawodawca zalicza tutaj koncentrację podaży i popytu na towary giełdowe, zapewnienie bezpiecznego i sprawnego przebiegu transakcji giełdowych i rozliczeń oraz upowszechnianie jednolitych informacji umożliwiających ocenę aktualnej wartości towarów giełdowych. Z perspektywy podstawowych założeń gospodarczych ekologicznego rynku kapitałowego znaczenie giełdy jako rynku cyrkulacji składników majątkowych wiąże się przede wszystkim w dążeniem do osiągnięcia efektu w postaci efektywnego zagospodarowania wyprodukowanej energii elektrycznej. Działalność giełdy pozwala na optymalne dostosowanie podaży do popytu, a co za tym idzie także optymalne zagospodarowanie infrastruktury produkcyjnej oraz przesyłowej.

Podmiotowym substratem giełdy są jej członkowie. Członka giełdy ze spółką prowadzącą giełdę łączy umowa o członkostwo giełdowe (art. 2 pkt 5 u.g.t.). Tylko członkowie giełdy - zasadniczo - są uprawnieni do zawierania transakcji giełdowych (art. 2 pkt 3 u.g.t.). Członkostwo giełdowe ma charakter ekskluzywny, ponieważ status członka giełdy jest zarezerwowany wyłącznie dla wybranych kategorii osób prawa prywatnego (art. 9 ust. 3 u.g.t.), a mianowicie towarowych domów maklerskich, domów maklerskich („finansowych”), przedsiębiorstw energetycznych oraz będących osobami prawnymi odbiorców uprawnionych do zmiany sprzedawcy $\mathrm{w}$ rozumieniu ustawy $\mathrm{z}$ dnia 10 kwietnia 1997 r. - Prawo energetyczne, grup producentów rolnych, niektórych zagranicznych osób prawnych oraz niektórych spółek handlowych.

W realiach obrotu zdematerializowanego drugim po giełdzie podmiotem infrastruktury jest izba rozrachunkowa. Pod tym względem podmiotowe otoczenie konwencjonalnego rynku kapitałowego różni w porównaniu z ekologicznym rynkiem kapitałowym. Na arenie konwencjonalnego rynku kapitałowego funkcje depozytu papierów wartościowych, izby rozliczeniowej oraz 2/2016 izby rozrachunkowej pełnią dwie osoby prawne - depozyt oraz 
izbę rozrachunkową prowadzi Krajowy Depozyt Papierów Wartościowych S.A. (KDPW S.A.), natomiast izbę rozliczeniową (o statusie ccp, czyli central counterparty) prowadzi KDPW_CCP S.A., całkowicie zależna kapitałowo od KDPW S.A. Natomiast w sektorze ekologicznego rynku kapitałowego ukształtowanie systemu depozytowo-rozliczeniowo-rozrachunkowego przedstawia się inaczej.

Nie wchodząc w szczegóły, można powiedzieć, że zadania depozytowe są rozproszone pomiędzy kilkoma osobami. Dywergencję w tym zakresie należy traktować jako coś oczywistego, ze względu na różnice leżące u podstaw systemowych założeń rynku kolorowych certyfikatów i wywodzących się z nich praw majątkowych do świadectw pochodzenia energii z odnawialnych źródeł oraz rynku uprawnień do emisji dwutlenku węgla do atmosfery. W przypadku praw majątkowych do świadectw pochodzenia rolę depozytu pełni Rejestr Świadectw Pochodzenia prowadzony przez TGE S.A. (niektóre czynności wykonuje Prezes Urzędu Regulacji Energetyki). Natomiast w przypadku uprawnień do emisji dwutlenku węgla do atmosfery zadania depozytowe pełni krajowy ośrodek bilansowania i zarządzania emisjami. W tej roli występuje Instytut Ochrony Środowiska w Warszawie, na podstawie art. 4 ust. 1 ustawy z dnia 17 lipca 2009 roku o systemie zarządzania emisjami gazów cieplarnianych i innych substancji ${ }^{15}$.

Rozliczanie i rozrachunek zawartych umów giełdowych to czynności należące do izby rozliczeniowej oraz izby rozrachunkowej. Różnicuje je sam ustawodawca. De lege lata (art. 45b ust. 1 u.o.i.f.) rozliczenie transakcji polega na ustaleniu wysokości świadczeń pieniężnych i niepieniężnych wynikających z zawartych transakcji, w ramach przyjętego sposobu rozliczenia, do których są zobowiązani lub uprawnieni. Natomiast w świetle art. 45b ust. 2 u.o.i.f. rozrachunek polega na obciążeniu lub uznaniu konta depozytowego, rachunku zbiorczego lub rachunku papierów wartościowych, a także na uznaniu lub obciążeniu rachunku bankowego lub rachunku pieniężnego wskazanego przez uczestnika będącego stroną transakcji albo stroną rozli-

15 Tekst jedn. Dz. U. z 2013 r., poz. 1107 ze zm. 
czenia. Pod względem podmiotowego ukształtowania systemu depozytowo-rozliczeniowo-rozrachunkowego zasadnicza wiązka kompetencji na konwencjonalnym rynku kapitałowym została rozszczepiona pomiędzy KDPW S.A. (izba rozrachunkowa) oraz KDPW_CCP S.A. (izba rozliczeniowa). Natomiast w obrocie walorami ekologicznego rynku kapitałowego oba zadania są skoncentrowane w gestii Izby Rozliczeniowej Giełd Towarowych S.A. (IRGiT S.A.).

Kolejną, ostatnią omówioną na tym miejscu kategorią podmiotów infrastruktury ekologicznego rynku kapitałowego są pośrednicy rynkowi. W tej grupie uczestników ekologicznego rynku kapitałowego najpoważniejszą rolę odgrywają towarowe domy maklerskie oraz domy maklerskie z sektora finansowego. Znaczenie banków prowadzących działalność maklerską oraz zagranicznych firm inwestycyjnych jest w praktyce znikome. Banki prowadzące działalność maklerską ze względu na specjalizację profilu działalności nie wykazują aktywności w sektorze obrotu walorami ekologicznego rynku kapitałowego (o czym świadczy m.in. analiza składu osobowego członków TGE S.A.). To samo odnosi się do zagranicznych firm inwestycyjnych. Typowy model prowadzenia przez firmy inwestycyjne działalności w sektorze towarowym wiąże się z powołaniem nowej osoby prawnej i uzyskaniem licencji KNF na prowadzenie działalności maklerskiej.

Pełną paletę kompetencji giełdowych daje towarowym domom maklerskim oraz domom maklerskim sektora finansowego status członka giełdy. Działalność tej kategorii uczestników ekologicznego rynku kapitałowego obejmuje przede wszystkim świadczenie usług pośredniczenia giełdowego, prowadzenie rachunków i rejestrów towarów giełdowych, a także doradztwo w zakresie obrotu giełdowego. Podstawą świadczenia tych czynności maklerskich jest umowa o świadczenie usług o treści zsynchronizowanej z ustawowym typem czynności maklerskiej. 


\section{PERSPEKTYWY ROZWOJU EKOLOGICZNEGO RYNKU KAPITAEOWEGO}

W obecnym stanie rozwoju stosunków społecznych brak podstaw do przyjęcia, że proces zbliżania się do siebie prawa ochrony środowiska naturalnego oraz prawa rynku kapitałowego osiągnął już swoje apogeum. Jest raczej wprost przeciwnie. Można bowiem spodziewać się dalszego przenikania się obu dziedzin dogmatycznych, chociaż trudno - oczywiście - precyzyjnie przewidywać dalsze kierunki tego mariażu. Zależności pomiędzy szeroko rozumianą dziedziną ochrony środowiska naturalnego oraz rynkiem kapitałowym zostały zauważone już dawniej, a czas pokazał, że prognozy odnośnie tego stanu W znacznym stopniu ziściły się. Przedstawiciele nauki o gospodarce zwracali uwagę na wysoki stopień przydatności emisji papierów wartościowych w celu sfinansowania inwestycji przyjaznych środowisku ${ }^{16}$, formułującą się koncepcję banku ekologicznego ${ }^{17}$, czy też rodzącą się zależność pomiędzy ekologicznym rynkiem kapitałowym oraz szerszym pojęciem społecznej odpowiedzialności biznesu (CSR) ${ }^{18}$. Te same procesy dostrzega też ustawodawca, zwłaszcza na obszarze regulacji prawnych poświęconych produkcji i dystrybucji energii oraz jej nośników.

Wymowną wskazówką dla prognozowania dalszych kierunków rozwoju zależności pomiędzy dziedziną ochrony środowiska naturalnego oraz prawem rynku kapitałowego jest z pewnością normatywne przekwalifikowanie uprawnień do emisji dwutlenku węgla do atmosfery, co stało się za sprawą dyrektywy z dnia 15 maja 2014 roku Parlamentu Europejskiego i Rady 2014/65/UE w sprawie rynków instrumentów finansowych

16 Zob. L. Dziawgo, Papiery wartościowe $w$ ochronie środowiska, Toruń 1997, s. 11 i nast.

17 Zob. L. Dziawgo, Pozyskiwanie kapitałów osób fizycznych na rynku finansowym $w$ celu ochrony środowiska naturalnego, Toruń 1998, s. 59 i nast.

18 Zob. L. Dziawgo, Zielony rynek finansowy. Ekologiczna ewolucja rynku finansowego, Warszawa 2010, s. 91 i nast. oraz 182 i nast. 
(MiFID 2 z 2014 r. $)^{19}$. Wraz z jej wejściem w życie uprawnienia do emisji dwutlenku węgla do atmosfery uzyskały status instrumentów finansowych (wcześniej miały status towarów giełdowych). Taka permutacja świadczy o rozprzestrzeniającym się reżimie prawa rynku kapitałowego na nowe obszary cyrkulacji praw podmiotowych - nie wyłączając dziedziny ochrony środowiska naturalnego. W prawie ochrony środowiska mamy coraz więcej prawa rynku kapitałowego i vice versa. Na kanwie tej obserwacji konkluzja finałowa jest - jak się wydaje - obiecująca. Wszystko wskazuje bowiem na to, że dziedzina ochrony środowiska naturalnego zasługuje na tak dużą uwagę, że w poszukiwaniu nowoczesnych mechanizmów regulacyjnych ustawodawca sięga z dużą pomyślnością po instytucje prawne skrajnie różne z perspektywy otoczki instytucjonalnej (konstrukcyjnej), ale doskonale zsynchronizowane ze sobą jeżeli chodzi o cel (aspekt teleologiczny).

\section{BIBLIOGRAFIA}

Dziawgo L., Papiery wartościowe w ochronie środowiska, Toruń 1997.

Dziawgo L., Pozyskiwanie kapitałów osób fizycznych na rynku finansowym w celu ochrony środowiska naturalnego, Torun 1998.

Dziawgo L., Zielony rynek finansowy. Ekologiczna ewolucja rynku finansowego, Warszawa 2010.

Zacharzewski K., Makler niezależny wedtug przepisów ustawy o giełdach towarowych, „Przegląd Ustawodawstwa Gospodarczego” 2002, Nr 5.

Zacharzewski K., Wykonywanie działalności maklerskiej przez maklera niezależnego $w$ giełdowym obrocie towarowym, „Przegląd Ustawodawstwa Gospodarczego" 2002, Nr 11.

Kontakt e-mail:

Konrad.Zacharzewski@umk.pl

19 Dyrektywa Parlamentu Europejskiego i Rady 2014/65/UE z dnia 15 maja 2014 roku w sprawie rynków instrumentów finansowych oraz zmieniająca dyrektywę 2002/92/WE i dyrektywę 2011/61/UE; Dz. Urz. UE L 145 z dnia 12 czerwca 2014 r., s. 349. 